\title{
Characterization of functional fish ham produced from Silver carp (Hypophthalmichthys molitrix) surimi enriched with natural antioxidant and vegetable fiber
}

\author{
Ebrahim Mahdavi ${ }^{1}$, Peiman Ariaii ${ }^{2, *}$ \\ ${ }^{1}$ Department of Food Science \& Technology, Nour Branch, Islamic Azad University, Nour, Iran; ${ }^{2}$ Department of Food \\ Science E Technology, Ayatolla Amoli Branch, Islamic Azad University, Amol, Iran
}

*Corresponding Author: Peiman Ariaii, Department of Food Science E Technology, Ayatolla Amoli Branch, Islamic Azad University, Amol, Iran, Email: p.aryaye@yahoo.com

Received: 23 May 2021; Accepted: 27 June 2021; Published: 23 August 2021

(C) 2021 Codon Publications

OPEN ACCESS (c) ()요 (2)

PAPER

\begin{abstract}
In this study, the effect of grape pomace (GE), orange peel extract (OE), and nisin $(\mathrm{N})$ with modified atmosphere packaging (MAP: $70 \% \mathrm{CO}_{2}+30 \% \mathrm{~N}_{2}$ ) was investigated on the quality and shelf life of ham produced from low fat Silver carp surimi (containing inulin fiber [FI] and salatrim [S]) kept in the refrigerator with T1: control (containing nitrite), T2: control + MAP, T3: GE 0.5\%+ FI 5\% +OE 0.5\% +N 0.5\%, T4: S 5\%+ OE 0.5\%+ GE 0.5\% +N $0.5 \%+$ MAP, T5: FI $2.5 \%+\mathrm{S} 2.5 \%+\mathrm{GE} 0.5 \%+\mathrm{OE} 0.5 \%+\mathrm{N} 0.5 \%+$ MAP. The texture characteristics of ham at the beginning of storage, cooking loss, chemical indices (peroxide value, $\mathrm{pH}$, color index), and microbial (total count bacteria, psychrotrophic bacteria, mold and yeast, Clostridium botulinum) during 42 days storage in the refrigerator $\left(4 \pm 1^{\circ} \mathrm{C}\right)$ were evaluated. The results of the tests were analyzed according to Duncan's by SPSS software with $95 \%$ confidence. The results showed that inulin and salatrim fibers have a positive effect on the texture and cooking loss of ham and inulin had a better effect, so the value of cooking loss in treatment 3 was $1.62 \%$ and control treatment was $2.09 \%$. Using three natural preservatives along with MAP could slow down the oxidative spoilage, microbial and color index changes in ham. These combinations also inhibited the growth of C. botulinum. In most tests examined, treatment 3 showed no significant difference with treatment 1 (ham containing nitrite) $(P>0.05)$, so this treatment shows that natural additives (nitrite replacement) improve the quality properties of low-fat ham.
\end{abstract}

Keywords: fat replacement; fish ham; inulin fiber; nisin; plant extracts

\section{Introduction}

Seafood is one of the most important sources of protein and have a considerable role in the health of consumers. Surimi is one of the minced fish products, which has been a traditional method of fish preservation. In general, surimi refers to minced and washed fish, which can be used for a variety of food products such as fish sausage, fish ham, fish cake, fish burger, and other products (Jin et al., 2017; Ozpolat and Patir, 2015; Shabanpour et al., 2007; Zhang et al., 2020). One of the meat products is ham which is very common in different parts of the world. These products have low oxidative stability and are sensitive to fat rancidity during storage. Therefore, some additives are used to control microbial load and oxidative changes in meat products. One of the main ways of processing meat products is the use of nitrate and nitrite. These compounds increase the shelf life and also prevent the spoilage of products during storage (Riazi et al., 2016; Nogueira et al., 2019). Salt and nitrite are also used to increase the shelf life and taste of the meat. Due to the chemical structure of nitrite in sausage and ham, its carcinogenic potential and also in response to consumer demand for natural products, reducing nitrite utilization 
or replacing all or part of it in meat products with natural compounds have been considered (Shu et al., 2020). Here are some of the compounds that have antioxidant and antimicrobial activity as nitrite substitutes (Araújo et al., 2019).

Citrus (Citrus reticulata, Blanco) is one of the most important fruits in the world. It contains minerals, phenolics, pectin, and dietary fiber, and is rich in vitamins $B$, $\mathrm{A}$, and $\mathrm{C}$; as a result, they have nutritional and medicinal properties. Nearly a hundred industries use citrus to produce their products (Drosou et al., 2015). One notable point in the citrus industry is the added value of these products through the production of by-products such as citrus peel. These are rich in flavones, polymethoxylates, and phytochemicals, which are rare in other plants, resulting in recent years, special attention has been paid to the use of citrus peel. Grape pomace (GE) is one of the many wastes (5000 tonnes per year) produced by juice factories, a rich source of several valuable compounds such as citric acid, tartrate, dietary fiber, and phenolic compounds. Anthocyanin (malvidin and penonidine), flavonol (quercetin and meristine), and phenolic acids are the major phenolic compounds and flavan-3-L, catechin, and epi-catechin, and gallic acid are the predominant phenolic compounds in GE (Batpho et al., 2017).

Bacteriocin-nisin (N) is from group A antibiotics with 34 amino acids that have a ring structure. In the nisin structure, there is a part called the hinge area which is capable of disassembling the ring systems and is characterized by its flexibility. Nisin has no inhibitory effect on gram-negative bacteria, yeasts, and fungi (Siroli et al., 2016). This bacteriocin was first synthesized by Lactococcus lactis in England in 1928 by Rogers and Whitier and was reported by the Food and Agriculture and World Health Organization (FAO/WHO) in 1969, for its low toxicity to humans, as a GARS ${ }^{1}$ and food preservative. Since 1987, it has been used as a permitted additive in food and dairy products (Hematian Sourki et al., 2012).

Packaging is another way to increase food shelf life. Modified atmospheric packaging (MAP) is used for the shelf life of fresh (non-frozen) food. The use of vacuum, MAP, and high $\mathrm{CO}_{2}$ packaging is easily feasible for processed meats, but high levels of $\mathrm{CO}_{2}$ will have negative effects on product quality, especially texture changes and increased blood loss (Ashraf et al., 2011; Ghosh and Dash 2020).

Fat is one of the important constituents that affect the sensory properties of food products, including flavor, color, texture, oral sensation, and overall

${ }^{1}$ Generally Recognized as Safe. sensory satisfaction. In general, an increase in fat and oil increases the frying ability and reduces the fragility of the tissue. However, its reduction results in a firm and gummy texture with low moisture content (Akalin and Erisir, 2008). On the other hand, a high intake of fats and oils can increase blood triglycerides, leading to cardiovascular disease and heart failure, so their consumption should be reduced. Inulin is a non-digestible carbohydrate-containing natural fructooligosaccharides and 1-2 glucopyranose residues. It has dietary fiber properties and due to its specific health and technological properties, there is a great interest in its use. The characteristic of inulin as a mimetic lipid is related to its ability to bind to water molecules and form a gellike network. Inulin also makes the mouth feel greasy. This property has been used in the production of fatfree yogurt, chocolate, imitated cheeses, ice cream, and low-fat fermented sausages, and the results indicate no change in the organoleptic properties of the products (Ognean et al., 2006; Shi et al., 2020). Another fat replacement is salatrim. Salatrim (derived from small and large molecules of triacylglycerides) is a generic name for a family of triglycerides that contains a mixture of at least one short-chain fatty acid (mainly C4:0, Cs:0, $\mathrm{C} 2: 0$ ) and at least one long-chain fatty acid (mostly stearic acid Cus: 0 ) that locates randomly on glycerol. This triglyceride has the physical properties of fat, but only contains 5 calories per gram instead of 9 calories per gram of natural fat (Surendra Babu et al., 2018)

Menegas et al. (2013) reported that fermented chicken sausages formulated with standard amounts of corn oil, reduced amounts of oil, and reduced amounts of oil containing inulin as a partial oil substitute remained stable and had no substantial loss of physical, chemical, microbiological, or sensory attributes during storage at $4^{\circ} \mathrm{C}$ for 45 days.

In this study, we evaluated the effect of natural antioxidants as a nitrite substitute and the use of fat substitutes to reduce oil in ham formulations produced from Silver carp surimi as well as MAP for the increased shelf life of the ham.

\section{Material and Methods}

\section{Raw materials}

At first, $30 \mathrm{~kg}$ of Silver carp were caught from the farms (1 hectare) and transported to the laboratory with ice boxes $\left(0^{\circ} \mathrm{C}\right)$, followed by washing and peeling. After this step, the underlying meat was removed without contact with the viscera and then it was ground first through a $10 \mathrm{~mm}$ plate and then through a $5 \mathrm{~mm}$ plate in a meat grinder (MKG1300P, Panasonic, Japan). 


\section{Preparation of treatments}

To prepare the surimi, minced meat was washed with drinking water at a temperature below $10^{\circ} \mathrm{C}$ for $10 \mathrm{~min}$ in three stages. Rinsing was performed in $0.2 \%$ brine in the third step. The later step caused better dehydration and reduced solubility of sarcoplasmic proteins in the salt solution. Surimi obtained during experiments was stored at refrigerator temperature (Shabanpour et al., 2007). For samples preparation (control treatment), the raw materials were weighed and blended to obtain a uniform paste according to the formulations (Table 1). For this purpose, the meat was placed with a third of the ice in the cutter (Talsa, E-46950, EU) and was mixed with the high-speed cutter, followed by nitrate, protein residues with ice, carbohydrates, fillers, vitamin $\mathrm{C}$, and finally, spices were added into the meat. After mixing, the components of the cutter and paste mixture were filled into the wrapper, the ham was incubated in the baking chamber at $85^{\circ} \mathrm{C}$ for 45 min (Bourne, 2002; Hayes et al., 2009). Inulin and salatrim fibers were added to the primary ham formulation as a fat substitute.

In addition, a ranking test previously performed comparing ham samples with inulin fiber and salatrim at different concentrations showed significantly lower acceptability of the samples incorporating $6 \%$ or $7 \%$ of them when compared to the rest (5\% or lower) (data not shown).

Table 1. Formulation and components of ham (control treatment).

\begin{tabular}{llc} 
Row & Components & $\%$ \\
\hline 1 & Fish meat (surimi) & 55 \\
2 & Oil & 10 \\
3 & Egg yolk & 1 \\
4 & Starch & 1 \\
5 & Gluten & 1 \\
6 & Skim milk & 3 \\
7 & Wheat & 3 \\
8 & Spice & 1 \\
9 & Salt & 1.2 \\
10 & Garlic & 1 \\
11 & Sugar & 0.5 \\
12 & Phosphate & 0.4 \\
13 & Vitamin C & 0.05 \\
14 & Nitrite & 0.012 \\
15 & Ice+ water & 20 \\
16 & Citrate & 1 \\
17 & Casein & 0.5 \\
18 & Sodium glutamate & 0.288 \\
19 & Glucono Delta Lactone & 0.05 \\
\hline & &
\end{tabular}

After these, with inulin fiber, salatrim concentrations of $5 \%$ were chosen as optimal for the following study. Fat decreased by $5 \%$. Also, extracts of orange peel, grape pomace, and nisin in the concentration of $0.5 \%$ (concentration approved by sensory evaluators unchanged in the taste of fish ham) were added combined as a substitute for part of nitrite and then, same steps were taken as that of control treatment and finally the treatments were packed into three multilayer flexible pouches ( 3 and 4 layers) under modified atmosphere (MAP: $70 \% \mathrm{CO}_{2}+30 \% \mathrm{~N}_{2}$ ).

The treatments were kept at refrigerator temperature $\left(4 \pm 1^{\circ} \mathrm{C}\right)$ for 42 days. On the $0,7,14,28,35$, and 42 days of storage, three hams from each section were randomly selected and tested to determine qualitative parameters (physicochemical and microbiological). All experiments were performed with three replications.

In total, five treatments were studied:

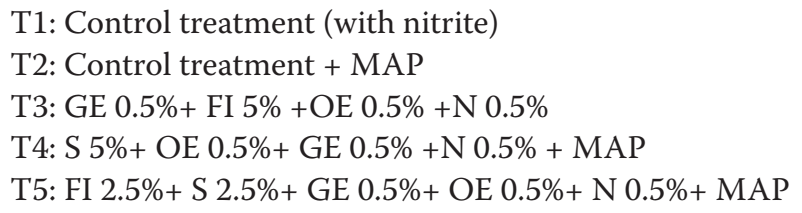

\section{Cooking loss test}

The cooking loss test was performed according to the method given by Hayes et al. (2009) with slight modification. Thirty grams of samples were stuffed into screw-top test tubes and were heated in a steam bath at $70^{\circ} \mathrm{C}$ for $30 \mathrm{~min}$. The cooked samples were quickly immersed in cool water for $10 \mathrm{~min}$. Cooking loss was determined by weighing individual samples before and after cooking, and the difference was expressed as a percentage of the original weight.

\section{Texture analysis}

To measure the texture of the ham, the cubic pieces were cut into $1 \times 1 \times 1 \mathrm{~cm}^{3}$ dimensions and subjected to compression test by a texture analyzer with a flat probe profile of $40 \times 40 \mathrm{~mm}$ and a load of $10 \mathrm{~kg}$. The force required to compress the samples to $70 \%$ of their initial height was measured at a constant rate of $200 \mathrm{~mm} / \mathrm{min}$ (Vural, 2003).

\section{Chemical analyses}

\section{Peroxide value}

Peroxide values of different treatments were determined according to the Bagheri et al. method (2016). Results were expressed in meq oxygen $\mathrm{kg}^{-1}$ lipids. 


\section{pH value}

The $\mathrm{pH}$ values of different treatments were measured with a digital $\mathrm{pH}$ meter calibrated to $\mathrm{pH} 4$ and 7 standards (Valipour Kootenaie et al., 2017).

\section{Color test}

The color of the sausage was measured using the Hunterlab color flex colorimeter. The color test results include three Hunter indices $a^{*}, b^{*}$, and $L^{*}$; where, $L^{*}$ is a light symbol which is black (0) and white (100), $\mathrm{a}^{*}$ is a green-to-red symbol, where $-\mathrm{a}$ is green and $+\mathrm{a}$ is red, and $\mathrm{b}^{*}$ is blue to yellow symbol, where $+\mathrm{b}$ is yellow and $-\mathrm{b}$ is blue. The experiment was performed in triplicates (Choi et al., 2009).

\section{Microbial analyses}

Ten grams of each sample was mixed and homogenized with $90 \mathrm{~mL}$ sterile sodium chloride solution and the required dilutions were prepared. One milliliter of each dilution was used for culture by the pour plate method. Total count and psychrotrophic bacteria were counted on Plate Count Agar at $37^{\circ} \mathrm{C}$ for 2 days and $7^{\circ} \mathrm{C}$ for 10 days, respectively. The results were reported as $\log \mathrm{CFU} / \mathrm{g}$ (Javadian et al., 2017).

\section{Mold and yeast test}

Dilution of the sample was first prepared in Peptone Water broth, then transferred to a plate containing $\mathrm{DRBC}^{2}$ medium. Plates were aerobically incubated at $25^{\circ} \mathrm{C}$ for 5 days (ISIRI, 2008).

\section{Inoculation and enumeration of Clostridium botulinum to ham samples}

Approximately $10^{8} \mathrm{CFU} / \mathrm{mL}$ of Clostridium botulinum was added to the ham samples. The samples were then massaged to ensure complete mixing of the bacterium with the hams and placed in especially filled coatings in the baking chamber. At least 10 hams were considered for each treatment. All treatments were packed in zippered nylon bags and stored at refrigerator temperature $\left(4 \pm 1^{\circ} \mathrm{C}\right)$ during the experiment. For bacterial count at each sampling time, $1 \mathrm{~g}$ of sample was mixed with $9 \mathrm{~mL}$ of physiological serum and suspended for half an hour. Depending on the sample, the dilutions range from $10^{2}$ to $10^{4}$. One milliliter of diluted sample was poured into the petri dish and then $10-15 \mathrm{~mL}$ of SC agar medium at 44 to $47^{\circ} \mathrm{C}$ was added to the petri dish and thoroughly mixed. After solidification of the medium, about $10 \mathrm{~mL}$ of the same medium was poured into the petri dish. Plates were then placed in an anaerobic

${ }^{2}$ Dichloran Rose bengal Agar. jar and incubated at $37^{\circ} \mathrm{C}$ for $22 \mathrm{~h}$. At the end of incubation, all plates containing less than 150 colonies were selected and the black colonies on each plate indicating the probability of C. botulinum were counted (ISIRI, 1994).

\section{Statistical analysis}

All experiments were performed in a completely randomized design with three replications and the result was reported as mean \pm standard deviation. Statistical analysis of treatments was performed using SPSS 16.0 software by ANOVA. Significant differences were determined by the Duncan test at the level of 0.05 and figures were drawn using Microsoft Excel software.

\section{Results and Discussion}

\section{Texture analysis}

According to the results (Figure 1A), the replacement of oil with inulin fiber and salatrim increased the firmness
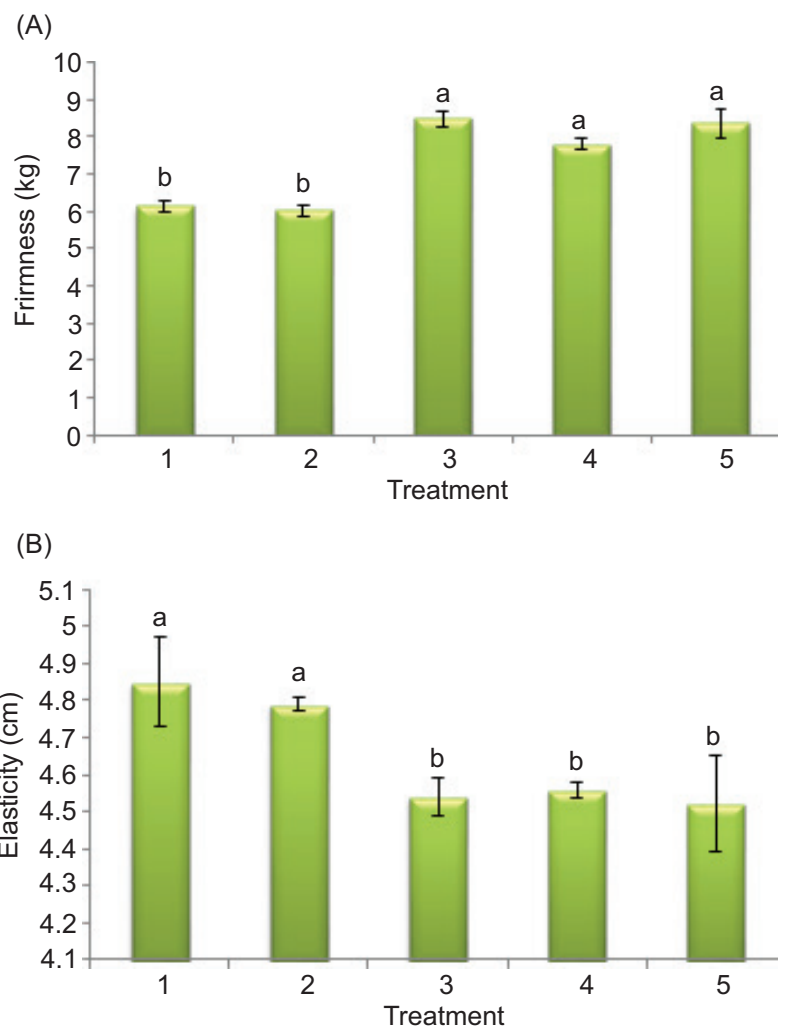

Figure 1. Texture analysis of different treatments of sausage [firmness (A); elasticity (B)] (T1: control, T2: control + MAP, T3: GE 0.5\%+ FI 5\% +OE 0.5\% +N 0.5\%, T4: S 5\%+ OE $0.5 \%+$ GE $0.5 \%+\mathrm{N} 0.5 \%+$ MAP, T5: FI $2.5 \%+$ S $2.5 \%+$ GE $0.5 \%+\mathrm{OE} 0.5 \%+\mathrm{N} 0.5 \%+\mathrm{MAP}$ ). Values with different superscripts are significantly different at $P<0.05$. 
values and the effect of inulin was significantly higher than salatrim. The lowest values were observed in control treatments (T1 and T2) and the highest values were observed in T3 (5\% inulin fiber) $(P<0.05)$. The final texture of food products is affected by the composition of the food. The interactions between proteins, starch, and other constituents are important for the final quality of the product. On this basis, compounds used probably enhance the ability of the meat proteins to bind and, as a result, tighten the ham texture. It also appears that lower oil content in T3 affects texture firmness than other treatments (Amina et al., 2014).

By definition, elasticity refers to the rate of return of the sample to its original state after removing the deformation force. Elasticity is directly related to the degree of rigidity of the treatment (Amina et al., 2014). According to the results (Figure 1B), the highest values were observed in control treatments (T1 and T2) and the lowest values were observed in T3. The results of the present study were consistent with the results of Menegas et al. (2013) by applying inulin fiber in chicken sausage fermented with corn oil to increase texture firmness and reduce sausage elasticity.

\section{Cooking loss}

The results of cooking loss (Figure 2) in the present study showed that with increasing time, the values of cooking loss increased in all treatments. Replacing the oil with inulin fiber and salatrim reduced the cooking loss. The effect of inulin on the reduction of cooking loss was significantly higher than salatrim. The highest values were observed in control treatments ( $\mathrm{T} 1$ and $\mathrm{T} 2$ ) on all days of storage and the lowest values were observed in T3 (5\% inulin fiber) $(P<0.05)$. In general, the fibers retain

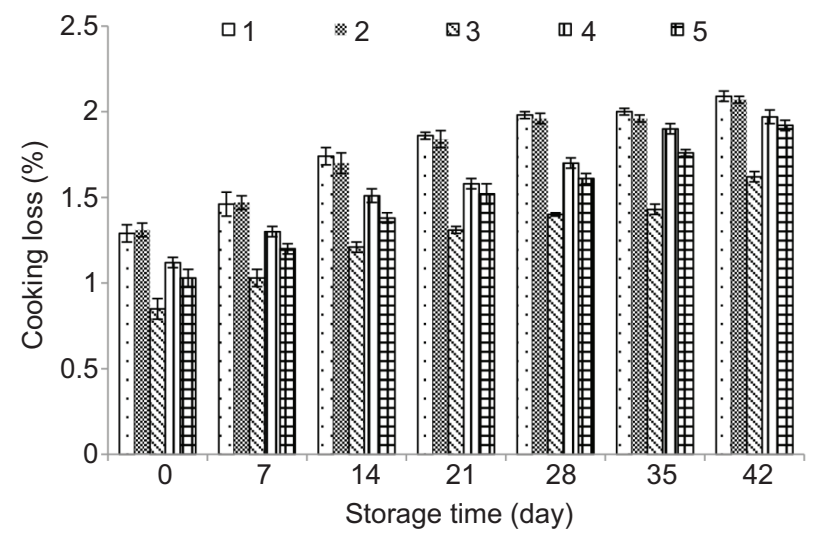

Figure 2. Cooking loss of different treatment during storage (T1: control, T2: control + MAP, T3: GE $0.5 \%+\mathrm{FI} 5 \%+\mathrm{OE}$ $0.5 \%+\mathrm{N} 0.5 \%$, T4: S $5 \%+$ OE $0.5 \%+$ GE $0.5 \%+\mathrm{N} 0.5 \%+$ MAP, T5: FI 2.5\%+ S 2.5\%+ GE 0.5\%+ OE 0.5\%+ N 0.5\%+ MAP). moisture during the frying process and are reduced cooking loss. This is due to their ability to form hydrogen bonds with water molecules, that is, to entrap water molecules, which prevents moisture outflow during the frying process (Farajzadeh et al., 2013; Marchetti et al., 2013). Amina et al. (2014) also reported that the addition of apple fiber reduced the cooking time of nugget meat.

\section{Peroxide value}

Lipid oxidation in meat is one of the causes of damage to meat tissue during storage. Oxidation of lipids in meat has a complex mechanism. During this process, in addition to the adverse effects on taste and color, protein solubility is also reduced and eventually nutritional value is declined (Valipour Kootenaie et al., 2017).

According to the results of the present study (Figure 3A), the peroxide value increased in all treatments with increasing time $(P<0.05)$, the increase of peroxide value in meat products was also reported by other researchers (Javadian et al., 2017; Valipour Kootenaie et al, 2017). According to the results, the lowest peroxide values were observed in the nitrite treatments with the MAP during storage $(P<0.05)$. This is due to the high amount of carbon dioxide used in MAP, which prevents the growth of aerobic and anaerobic bacteria.

The highest level of carbon dioxide in the MAP has been reported up to $50 \%$ (Silbande et al., 2018). The change in peroxide value in the inulin treatment was also slower than salatrim treatment. The lower peroxide value in the inulin treatment was due to the lower fat content which reduced oxidative spoilage. Also, using three preservatives together effectively controlled the increasing trend of peroxide value. The lowest values were observed in all days after T2, in T1 and T3. Most of the time, the latter treatments did not have significant differences $(P<$ $0.05)$. The antioxidant properties of plant extracts depend on phenolic compounds. Polyphenols are capable of trapping free radicals, especially proxy radicals, which are one of the key intermediate chain reactors, thereby terminating the cycle of oxidative spoilage reactions (Valipour Kootenaie et al., 2017). Also, bacteriocin-nisin can decrease peroxide value by decreasing the population of lipase-producing bacteria (such as pseudomonas species) (Dehbandi et al., 2014). In total, these three preservatives together with MAP can have similar effect with nitrite on ham.

The permitted level of peroxide value in the aquatic product for human consumption is 5 meq oxygen $\mathrm{kg}^{-1}$ lipids (Yanar, 2007). According to the results at the end of the storage period, peroxide value was lower than the acceptable range in all samples except $\mathrm{T} 4$. 


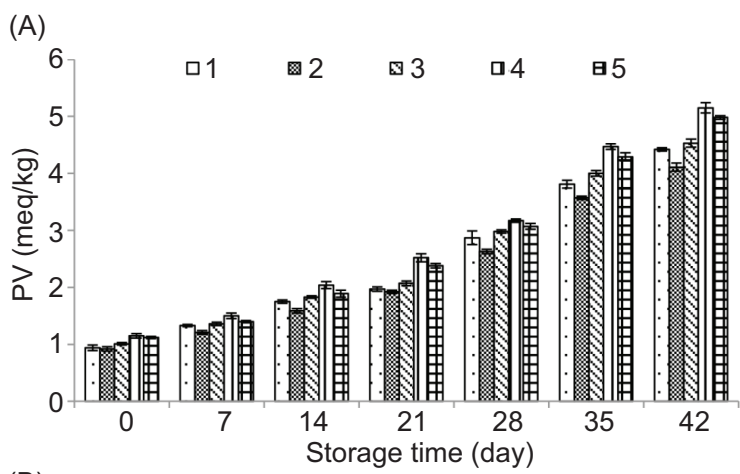

(B)

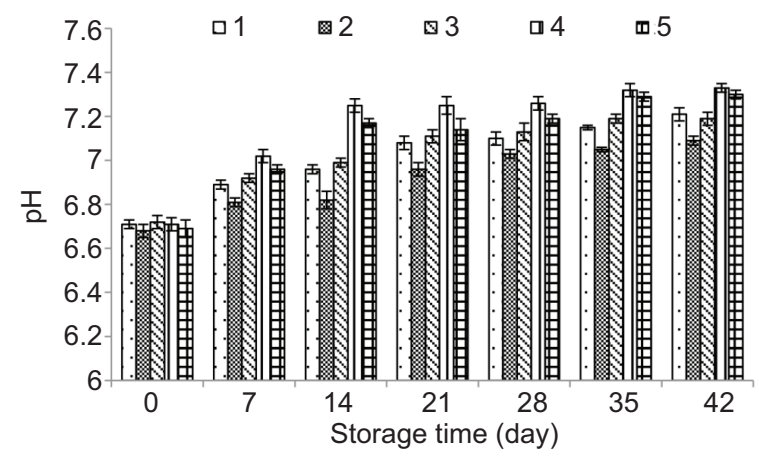

Figure 3. Peroxide value (PV) (a) and pH (b) of different treatment during storage period (T1: control, T2: control + MAP, T3: GE $0.5 \%+$ FI $5 \%$ +OE $0.5 \%+\mathrm{N} 0.5 \%$, T4: S $5 \%+$ OE $0.5 \%+$ GE $0.5 \%+\mathrm{N} 0.5 \%+$ MAP, T5: FI $2.5 \%+$ S $2.5 \%+$ GE $0.5 \%+0 E 0.5 \%+N 0.5 \%+$ MAP).

\section{$\mathrm{pH}$ values}

Even during frozen storage that the microorganisms are inactive, the previously produced enzymes and the endogenous enzymes in the meat are active. The results of $\mathrm{pH}$ values in ham (Figure 3B), in the present study, showed that with increasing time, $\mathrm{pH}$ values increased in all treatments. The increase in $\mathrm{pH}$ during storage can also be attributed to the production of volatile nitrogenous bases (such as ammonia and trimethylamine) resulting from the activity of meat-spoilage bacteria (Valipour Kootenaie et al., 2017). The use of MAP slowed the $\mathrm{pH}$ increasing trend. Since high levels of carbon dioxide reduce bacterial growth, therefore, the $\mathrm{pH}$ increasing trend is slower than the control treatment. In general, the lowest $\mathrm{pH}$ values were observed in nitrite + MAP treatment (T2) $(P<0.05)$. In general, the lowest values were observed in all days after T2 in T1 and T3 $(P<0.05)$. The latter treatments were not significantly different $(P>$ $0.05)$. The equivalence of $\mathrm{pH}$ values in the sample containing extract compared to the nitrite treatments can be related to the antibacterial activity of the extract. As the microbial flora decreases, the number of secondary metabolites produced decreases and the $\mathrm{pH}$ increasing trend is slowed (Vilela et al., 2016). The use of nisin also influences spoilage bacteria due to its antibacterial properties and reduces the capacity of the bacteria to oxidative deamination non-protein nitrogen compounds (such as ammonia and trimethylamine), thereby reduces the $\mathrm{pH}$-increasing process (Dehbandi et al., 2014).

\section{Color test}

The color index $\mathrm{L}$ indicates the brightness symbol (black to white). So the more $\mathrm{L}$ the meat is lighter. The color index $a$ is the indicator of the color change from green to red. The color index $\mathrm{b}$ represents the color change from blue to yellow. Results of color index showed that replacement of nitrite with preservatives reduced color index $\mathrm{L}$ and $\mathrm{a}$ and increased color index $\mathrm{b}$. Sodium nitrate and nitrite are used to create a bright red (pink) and to prevent the darkening of the meat products, as well as antimicrobial preservatives and to create a special flavor. So it seems natural to replace nitrite with other compounds and change its color. According to the results of using modified atmosphere, the color index L decreases (Figure 4A). Overall, the highest values were observed in control treatments. The other three treatments had no significant difference indicating a decrease in the oxidation process in ham. The brightness values of the ham samples are correlated with the peroxide values. As the number of peroxides increases, the brightness decreases and the samples darken. It can be stated that the use of three preservatives prevents the oxidation of pigments and act as a chemical preservative such as nitrite.

The color index a (Figure 4B) also decreased in all treatments. Generally, one of the causes of oxidation in meat products is the presence of compounds such as myoglobin and hemoglobin which in the presence of metals such as iron, act as peroxidants. This is one of the factors affecting the oxidation of oxymyoglobin (light red) to metmyoglobin (brown color) during the storage of meat products. Therefore, as a result of redox oxidation, color index a is reduced (Jin et al., 2007).

The color index b (Figure 4C) decreased and increased during the storage period, which was consistent with the results of Giatrakou et al. (2010). They reported that yellow index changes in meat products did not have a specific pattern and can change during storage by product type, formulation, and form of packaging.

\section{Total and psychrotrophic bacteria}

The results of total count bacteria (TVC) (Figure 5A) and psychrotrophic bacteria (PTC) (Figure 5B) were somewhat consistent $(P<0.05)$ and were increased during storage time $(P<0.05)$. The MAP decreased the growth of TVC and PTC so that the lowest values were observed in 
(A)

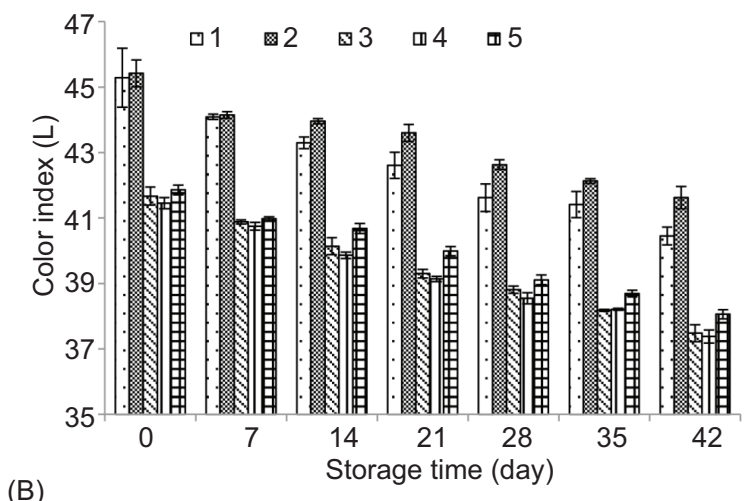

(B)

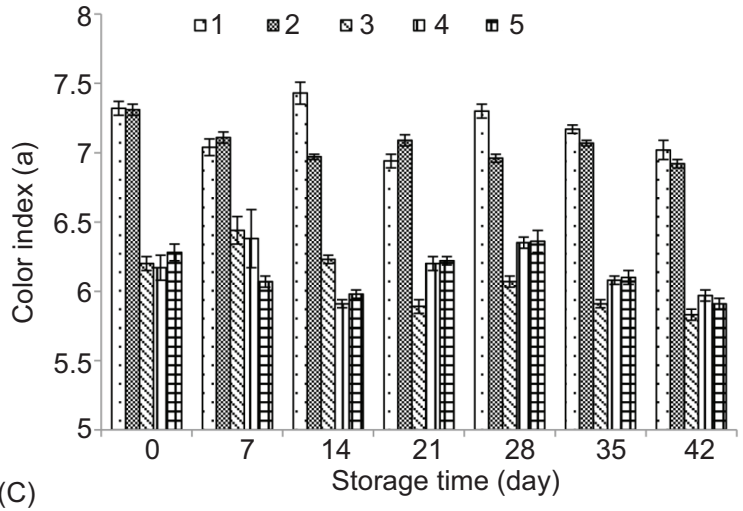

(C)

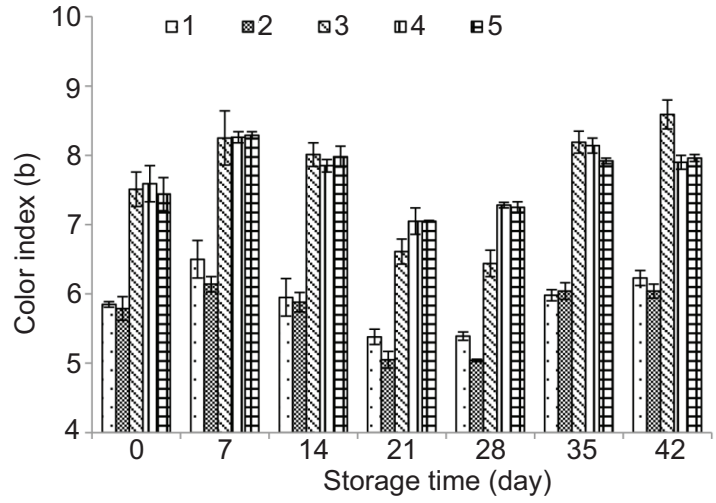

Figure 4. Color index $L, b$, and a (A, B, and C, respectively) of different treatment during storage period (T1: control, T2: control + MAP, T3: GE $0.5 \%+$ FI $5 \%+O E$ O. $0 \%+\mathrm{N} 0.5 \%$, T4: S 5\%+ OE $0.5 \%+$ GE $0.5 \%+\mathrm{N} 0.5 \%+$ MAP, T5: FI $2.5 \%+\mathrm{S}$ $2.5 \%+$ GE $0.5 \%+$ OE $0.5 \%+N 0.5 \%+$ MAP).

nitrite + modified atmosphere treatment (T2). Gases used in modified atmospheres such as carbon dioxide have antimicrobial activity and their mechanism is to dissolve in the water of the food and produce carbonic acid, which enters the cell membrane of the microorganism and after ionization, it disrupts the intracellular electrical balance and ultimately causes bacterial death (Ghosh and Dash 2020). The use of three preservatives together more effectively slowed down the growth of TVC. The lowest values were observed in all days of T2 and four other treatments had no significant difference $(P>0.05)$. Similar results
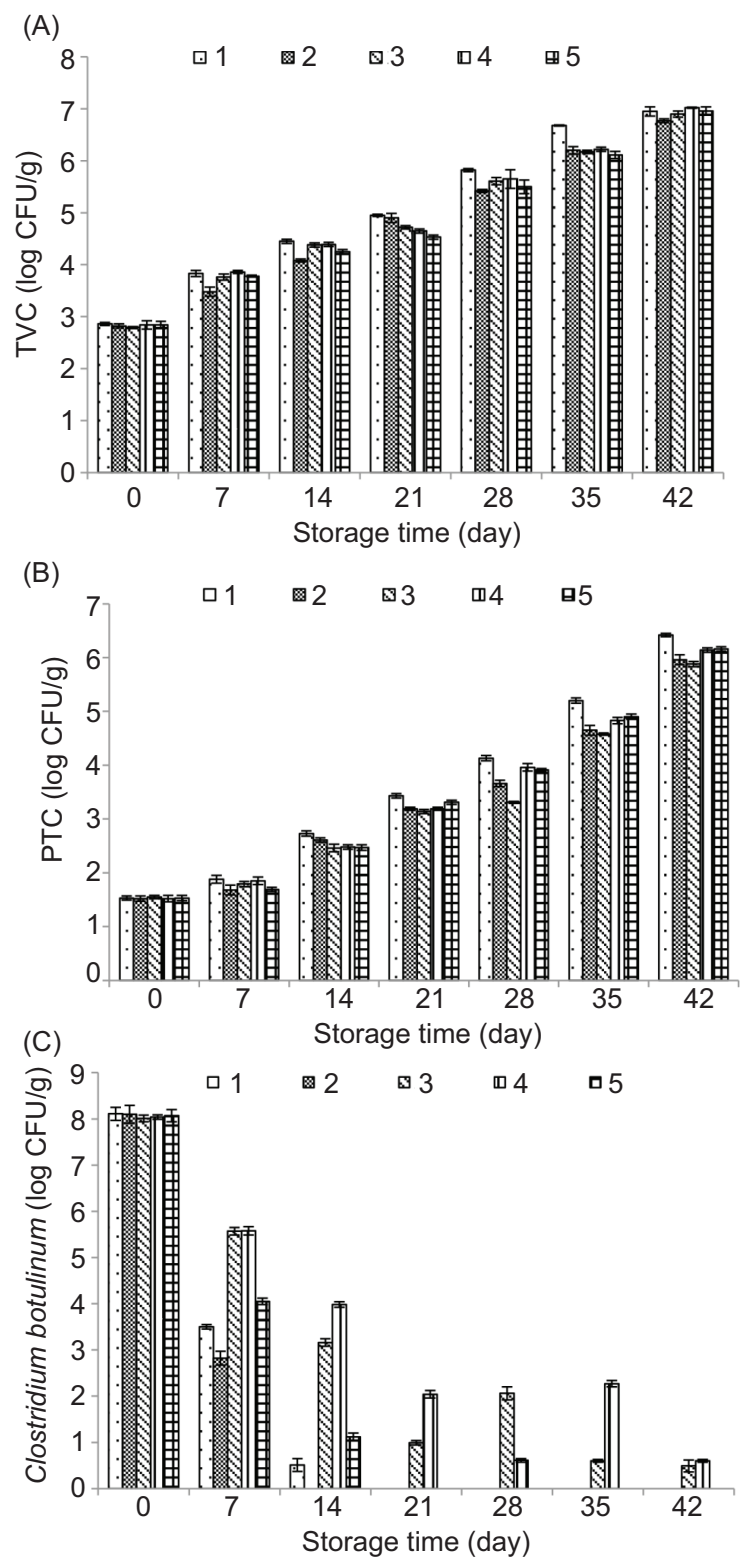

Figure 5. Total viable count (TVC) (A), psychrotrophic bacteria count (PTC) (B), and Clostridium botulinum (C) of different treatment during storage period (T1: control, T2: control + MAP, T3: GE $0.5 \%+$ FI $5 \%+$ OE $0.5 \%+\mathrm{N} 0.5 \%$, T4: S 5\%+ OE $0.5 \%+$ GE $0.5 \%+\mathrm{N} 0.5 \%+$ MAP, T5: FI $2.5 \%+$ S $2.5 \%+$ GE $0.5 \%+$ OE $0.5 \%+N 0.5 \%+$ MAP).

were observed with PTC bacteria indicating a positive effect of three preservatives as a substitute for nitrite in sausages. The lower TVC and PTC in the extract containing treatments can be due to phenolic compounds such as cineol. Phenolic compounds in plant extracts destroy the microorganisms and cause liposaccharides to exit and increase the permeability of the cytoplasmic membrane to $\mathrm{ATP}^{3}$. ATP release leads to the termination of cell

${ }^{3}$ Adenosine triphosphate. 
energy storage and cell death (Burt, 2004). Bacteriocinnisin also acts by creating gaps in the plasma membrane due to the wide inhibitory spectrum shown on bacteria in vegetative cells, so that cytoplasmic components seep out through the gaps, and after ATP hydrolysis, cell death occurs. The anionic lipid present in the membrane is an active site for nisin binding (Li et al., 2016).

In the present study, no mold and yeast were observed.

\section{Clostridium botulinum}

Clostridia are bacteria that occur in the environment and on the flora of the intestines of humans and animals (Wagner et al., 2006). These bacteria have different resistance to adverse environmental factors. However, it has been shown that sulphite-reducing clostridia can persist against high salt levels of ham and can tolerate subsequent processes such as pasteurization and high water activity $\left(\mathrm{a}_{\mathrm{w}}\right)$ reactivates them and risks to consumer health (Wagner et al., 2006). Therefore, the inactivation of these bacteria using natural preservatives is important. Results of C. botulinum (Figure 5C) showed that with increasing time, C. botulinum decreased in all treatments. According to the results of the MAP, the process of growth of C. botulinum was slowed so that on day 14 the lowest value of the bacterium was observed in control + MAP treatment (T2). The use of the preservative effectively inhibited the bacterium as no treatment was observed on day 21 due to the antimicrobial activity of the extracts. Phenolic compounds in plant extracts destroy microorganisms and result in the release of liposaccharides and increased permeability of the cytoplasmic membrane to ATP. ATP withdrawal results in the depletion of cell energy storage and cell death (Burt, 2004). Clostridium botulinum is a gram-positive bacterium, and the fact that nisin is effective against gram-positive bacteria and not effective against gram-negative bacteria has been well established. Nisin is specifically active against the vegetative cells and heat-resistant spores of Bacillus, Clostridium, and Listeria monocytogenes. The mechanism of nisin antimicrobial activity against the vegetative walls of cells is binding to the cytoplasmic membrane. Nisin is a cationic antimicrobial that binds to electrons with a negative charge through electrostatic bonding. After binding, nisin enters the membrane and creates a temporary small cavity. This process causes the rapid release of ions, amino acids, and cellular ATP (Vongsawasdi et al., 2012).

\section{Conclusions}

The results of the present study showed that the addition of inulin fiber and salatrim had a positive effect on the texture and cooking loss of ham, which had a higher effect of inulin fiber. Also, the use of three natural preservatives combined with MAP in most treatments had almost similar chemical and microbial properties compared to conventional ham treatment (containing nitrite). In all tests, among the treatments containing natural preservatives, the best results were obtained in T3 $(5 \%$ oil $+5 \%$ inulin fiber $+0.5 \% \mathrm{GE}$ extract $+0.5 \%$ orange peel extract $(\mathrm{OE})+$ $0.5 \% \mathrm{~N}+\mathrm{MAP}$ ), so the results can produce a functional low-fat, nitrite-free, fiber-containing product and natural antioxidants.

\section{References}

Akalin, A.S. and Erisir, D., 2008. Effect of inulin and oligofructose on the rheological characteristics and probiotic culture survival in low fat probiotic ice cream. Journal of Food Science 73: 184188. https://doi.org/10.1111/j.1750-3841.2008.00728.x

Amina, B., Parveen, S., Rather, S., Akhter, R. and Hassa, M., 2014. Effect of incorporation of apple pomace on the physic-chemical, sensory and textural properties of mutton nuggets. International Journal of Advanced Research 2(4): 974-983. ISSN 2320-5407.

Araújo, S., Matos, C., Correia E. and Antunes, M.C., 2019. Evaluation of phytochemicals content, antioxidant activity and mineral composition of selected edible flowers. Quality Assurance and Safety of Crops \& Foods 11(5): 471-478. https:// doi.org/10.3920/QAS2018.1497

Ashraf, S., Saeed, S.M.G., Sayeed, S.A., Ali, R., Saeed, H. and Ahmad, M., 2012. Effect of replacement through rice milling by-products on the rheological and baking behavior of dough. Journal of Agricultural Research 78: 5898-5904. https://doi. org/10.5897/AJAR12.1052

Bagheri, R., Izadi Amoli, R., Tabari Shahndash, N. and Shahosseini, S.R., 2016. Comparing the effect of encapsulated and unencapsulated fennel extracts on the shelf life of minced common kilka (Clupeonella cultriventris caspia) and Pseudomonas aeruginosa inoculated in the mince. Food Science and Nutrition 4(2): 216-222. https://doi.org/10.1002/fsn3.275

Batpho, K., Boonsupthip, W. and Rachtanapun, C., 2017. Antimicrobial activity of collagen casing impregnated with nisin against foodborne microorganisms associated with ready to eat sausage. Food Control 73: 1342-1352. https://doi.org/10.1016/j. foodcont.2016.10.053

Bourne, M.C., 2002, Food texture and viscosity: concept and measurement. 2nd ed. Elsevier Science \& Technology Books. 423pp.

Burt, S., 2004, Essential oils: their antibacterial properties and potential application in foods - a review. International Journal of Food Microbiology 94(3): 223-253. https://doi.org/10.1016/j. ijfoodmicro.2004.03.022

Choi, Y.S., Choi, J.H., Han, D.J., Kim, H.Y., Lee, M.A., Kim, H.Y., et al. 2009. Characteristics of low-fat meat emulsion systems with pork fat replaced by vegetable oils and rice bran fiber. Meat Science 82: 266-271. https://doi.org/10.1016/j.meatsci.2009.01.019

Dehbandi, A., Motallebi, A.A., Razavilar, V. and Pourgholam, R., 2014. Effect of nicin $\mathrm{z}$ on some of spoilage chemical and bacterial 
properties in surimi of kilka (Clupeonella cultriventris caspia) stored in $4^{\circ} \mathrm{C}$. Iranian Scientific Fisheries Journal 23(3): 41-56. http://aquaticcommons.org/id/eprint/22014.

Drosou, C., Kyriakopoulou, K., Bimpilas, A., Tsimogiannis, D. and Krokida, M.A., 2015, Comparative study on different extraction techniques to recover red grape pomace polyphenols from vinification byproducts. Industrial Crops and Product 75: 141-149. https://doi.org/10.1016/j.indcrop.2015.05.063

Farajzadeh, Z., Rahimi, E., Hojjatoleslamy, M. and Molavi, H., 2013. Production of low fat hamburger using hydrocolloid coatings. Journal of Food Hygiene 2(8): 61-70. https://www.sid.ir/en/ journal/ViewPaper.aspx?id=396172

Ghosh, T. and Dash, K.K., 2020. Modeling on respiration kinetics and modified atmospheric packaging of fig fruit. Food Measure 14: 1092-1104. https://doi.org/10.1007/s11694-019-00359-2

Giatrakou, V., Ntzimani, A. and Savvaidis, I., 2010. Effect of chitosan and thyme oil on a ready to cook chicken product. Food Microbiology 27: 132-136. https://doi.org/10.1016/j.fm.2009. 09.005

Hayes, J.E., StePanyan, V., Allen, P., O’Grady, M.N. and Kerry, J.P., 2009. Evaluation of the effects of selected plant-derived nutraceuticals on the quality and shelf-life stability of raw and cooked pork sausages. LWT-Food Science and Technology 44: 164-172. https://doi.org/10.1016/j.lwt.2010.05.020

Hematian Sourki, A., Ghiafeh Davoodi, M., Tabatabaei Yazdi, F., Mortazavi, S.A., Karimi, M., Razavizadegan Jahromi, S.H., et al. 2012. Studies on the effects of packaging type and modified atmosphere on properties of Barbari bread fortified with whole soy flour. FSCT 9(36): 77-85. Available at: http://fsct.modares. ac.ir/article-7-11712-en.html

Institute of Standards and Industrial Research of Iran (ISIRI), 1994. Searching and enumeration of Clostridium perfringens in food (Standard No. 2197). Iran

Institute of Standards and Industrial Research of Iran (ISIRI), 2008. Microbiology of food and animal feeding stuffs - horizontal method for the enumeration of yeasts and moulds - Part 1: colony count technique in products with water activity greater than 0.95 (Standard No. 10899-1).

Javadian, S.R., Shahoseini, S.R. and Ariaii, P., 2017. The effects of liposomal encapsulated thyme extract on the quality of fish mince and Escherichia coli O157: H7 inhibition during refrigerated storage. Journal of Aquatic Food Product Technology 26(1): 115-123. https://doi.org/10.1080/10498850.2015.1101629

Jin, S., Jeong, H. and Choi, J., 2017. Effect of surimi on quality characteristics of dry and semi-dry (non-fermented) pork sausages during cold storage. Food Measure 11: 1370-1377. https://doi. org/10.1007/s11694-017-9515-4

Jin, S.K., Kim, I.S., Choi, Y.J. and Hur, S.J., 2007. The development of sausage including meat from spent laying hen Surimi. Poultry Science 86: 2676-2684. https://doi.org/10.3382/ps.2006-00451

Li, H., Xu, Z., Zhao, F., Wang, Y. and Liao, X., 2016. Synergetic effects of high- pressure carbon dioxide and nisin on the inactivation of Escherichia coli and Staphylococcus aureus. Innovative Food Science \& Emerging Technologies 33: 180-186. https:// doi.org/10.3382/ps.2006-00451
Marchetti, L., Andrés, S.C. and Califano, A.N., 2013. Textural and thermal properties of low-lipid meat emulsions formulated with fish oil and different binders. LWT - Food Science and Technology 51: 514-523. https://doi.org/10.1016/j.lwt.2012.12.006

Menegas, L, Colombo Pimentel, T, Garcia, S. and Helena Prudencio, S., 2013. Dry-fermented chicken sausage produced with inulin and corn oil: physicochemical, microbiological, and textural characteristics and acceptability during storage. Meat Science 93: 501-506. https://doi.org/10.1016/j.meatsci.2012.11.003.

Nogueira, H.B.R. and Arisseto-Bragotto, A.P., 2019. Food additives used in Brazilian meat products: compliance with current national legislation. Quality Assurance and Safety of Crops \& Foods 11(7): 623-629. https://doi.org/10.3920/QAS2018.1412

Ognean, C.F., Darie, N. and Ognean, M., 2006. Fat replaces. Journal of Agroalimentary Processes and Technologies 7(2): 442-443.

Ozpolat, E. and Patir, B., 2015. Determination of shelf life for sausages produced from some freshwater fish using two different smoking methods. Journal of Food Safety 36(1): 69-76. https:// doi.org/10.1016/j.lwt.2012.12.006

Riazi, F., Zeynali, F., Hoseini, H. and Behmadi, H., 2016. Effect of dry red grape pomace as a nitrite substitute on the microbiological and physicochemical properties and residual nitrite of dry-cured sausage. Nutrition and Food Sciences Research 3(3): 37-44. https://doi.org/10.18869/acadpub.nfsr.3.3.37

Shabanpour, B., Kashiri, B., Molodi, H. and Hosininejhad, A., 2007. Effects of washing bouts and times on surimi quality prepared from Common Carp (Cyprinus carpio). Iranian Journal of Fisheries Sciences, IFRO. Tehran, Iran 16: 81-92. (in Persian). https://www.sid.ir/en/journal/ViewPaper.aspx?id=91805

Shi, R., Li, T., Wang, C., Yu, H., Chen, W., Wang, Y., et al. 2020. Impacts of preliminary isolation and enzymatic treatment on antioxidant activities of glycosylated whey protein isolate with inulin. Food Measure 14: 3270-3279. https://doi.org/10.1007/ s11694-020-00568-0

Shu, B., Wu, G., Wang, Z., Wang, J., Huang, F., Dong, L., et al. 2020. The effect of microwave vacuum drying process on citrus: drying kinetics, physicochemical composition and antioxidant activity of dried citrus (Citrus reticulata Blanco) peel. Food Measure 14: 2443-2452. https://doi.org/10.1007/s11694-020-00492-3

Silbande, A., Adenet, S., Chopin, C., Cornet, J., Smith-Ravin, J., Rochefort, K., et al. 2018. Effect of vacuum and modified atmosphere packaging on the microbiological, chemical and sensory properties of tropical red drum Sciaenopsocellatus fillets stored at $4{ }^{\circ} \mathrm{C}$. International Journal of Food Microbiology 266: 31-41. https://doi.org/10.1016/j.ijfoodmicro.2017.10.015

Siroli, L., Patrignani, F., Serrazanetti, D.I., Vannini, L., Salvetti, E., Torriani, S., et al. 2016. Use of a nisin producing Lactococcus lactis strain, combined with natural antimicrobials, to improve the safety and shelf-life of minimally processed sliced apples. Food Microbiology 54: 11-19. https://doi.org/10.1016/j.fm.2015. 11.004

Surendra Babu, A., Parimalavalli, R. and Jagan Mohan, R., 2018. Effect of modified starch from sweet potato as a fat replacer on the quality of reduced fat ice creams. Food Measure 12: 24262434. https://doi.org/10.1007/s11694-018-9859-4. 
Valipour Kootenaie, F., Ariaii, P., Khademi Shurmasti, D. and Nemati, M., 2017. Effect of chitosan edible coating enriched with eucalyptus essential oil and $\alpha$-tocopherol on silver carp fillets quality during refrigerated storage. Journal of Food Safety 37(1): e12295. https://doi.org/10.1111/jfs.12295

Vilela, J., Martins, D., Monteiro-Silva, F., González-Aguilar, G., de Almeida, J.M. and Saraiva, C., 2016. Antimicrobial effect of essential oils of Laurus nobilis L. and Rosmarinus officinallis L. on shelf-life of minced "Maronesa" beef stored under different packaging conditions. Food Packaging and Shelf Life 8: 71-80. https://doi.org/10.1016/j.fpsl.2016.04.002

Vongsawasdi, P., Nopharatana, M., Supanivatin, P. and Promchana, M., 2012. Effect of nisin on the survival of Staphylococcus aureus inoculated in fish balls. Asian Journal of
Agricultural -Industry 5(01): 52-60. https://doi.org/10.22067/ ifstrj.v14i5.69107

Vural, H., 2003, Effect of replacing beef fat and tail fat with interesterified plant oil on quality characteristics of Turkish semi-dry fermented sausages. European Food Research and Technology 217(2): 100-103. https://doi.org/10.1007/s00217-003-0727-y

Wagner, K., Vorauer-Uhl, K. and Katinger, H., 2006. Nebulization of liposomal rhcu/zn Sod with a novel vibrating membrane nebulizer. Journal of Liposome Research 16, 113-125. https://doi. org/10.1007/s00217-003-0727-y

Yanar, Y., 2007, Quality changes of hot smoked catfish (Clarias gariepinus) during refrigerated storage. Journal of Muscle Foods 18: 391-400. https://doi.org/10.1111/j.1745-4573.2007.00094.x 